\title{
Sub-Saharan African Countries Public Expenditure and Economic Growth: Wagner's Panel Cointegration and Causality Applications
}

\author{
Choudhry Mohammad Hanif \\ Department of Economics \\ Faculty of Social \& Management Sciences \\ Bayero University Kano \\ Elsadig Musa Ahmed \\ Faculty of Business, Multimedia University, Melaka, Malaysia \\ E-mails: (elsadig.musa@mmu.edu.my, shelllshelll@yahoo.com)
}

\begin{abstract}
In this paper, the validity of the Wagner's law is investigated in tenth selected Sub- Saharan African countries, namely Botswana, Equatorial Guinea, Mauritania, Nigeria, South Africa, Sierra Leone, Tanzania, Ethiopia, Madagascar, and DR Congo. Five variants of the Wagner's law were tested for the period 2005-2014, using panel econometric approaches encompassing cointegration and causality. The study found a long run relationship between the public expenditure and the various explanatory variables used as proxies of income. The long-run causality tests indicate that there is bidirectional causality between expenditure and income in all models with the exemption of the Gupta model. It is concluded that for Sub-Saharan Africa, both the Wagner's law the Keynesian hypothesis tend to be valid under the period of investigation. The explanation is that there has been the tendency for public expenditure to grow relative to national income (Wagner's law) and that public expenditure is a policy instrument (an exogenous factor) for improving national income (Keynesian hypothesis) during the 10-year period.
\end{abstract}

Keywords: Economic growth; public expenditure; panel cointegration; Sub-Saharan Africa 


\section{Introduction}

The role that government ought to play in the life of an economy is one of the most debated issues in the economic literature. The size of public expenditure has expanded for most of the developed and developing world in the last one century, leading to renewed interest in what the optimal size of government might. Several theories have consequently been propounded to explain the relationship between growth and public expenditure. Many models and frameworks have resulted in the quest for an adequate and sufficient explanation on the growth-expenditure nexus.

Several reasons account for this interest. In the first place, the size and the composition of government spending is influenced by a multiplicity of factors with dimensions in the political, institutional and macroeconomic spectrum. Second, because of the imperatives of subjecting the economy to controls arising from endogenous and exogenous shocks, it has become necessary for many governments to use spending as a mechanism for achieving economic stability and macroeconomic management.

Third and very importantly, there are policy implications on the relationship between government expenditure and economic growth, considering that empirical investigations have largely proceeded from two dominant viewpoints, namely the Wagner's law and the Keynesian hypothesis. To this end, the validity of these contrasting views have been tested using different and alternative frameworks in both time series and cross sectional data (Courakis et al., 1993).

Peacock and Wiseman (1961), in a classic paper, attributed the growing interest in the associated problems of economic dynamics and economic growth as reasons which stimulated interest in public expenditures. They inquired: what is the relationship between the time 
evolution of public expenditures and of other magnitudes of economic interest? Wagner's law and Keynesian theory aimed at establishing generalizations about government expenditures by direct inference from historical evidence or using postulates about the logic of choice. Public expenditure or public spending is a major component whenever strategies for stimulating economic growth and development are discussed.

It is important to examine what impact public expenditure has on economic growth in subSaharan Africa. Since the mid-1990s, Sub-Saharan Africa began for the first time to grow at about the same rate as the rest of the world. In 2012, according to the International Monetary Fund (IMF, 2013), growth remained strong in the region with regional GDP rates increasing in most countries (excluding Nigeria and South Africa). For 2013 to 2014, the IMF projected a 51/2 percent moderate broad-based acceleration in growth for the sub region. It is pertinent to inquire the source and nature of the growth experienced in the period. In other words, what is responsible for this recent growth? Is it the size of the public sector (government spending) in these countries?

From the foregoing, the objective of the paper is to examine the validity of Wagner's law in Sub-Saharan Africa. The paper is divided into five sections. Following the introduction, section 2 is on literature and theoretical issues. Methodology is covered in section 3. The empirical results of the study are presented and discussed in section 5. The paper is concluded in section 5 .

\section{Literature Review}

The relationship between government spending and national income has been investigated in two different ways in two major areas of economic analysis, i.e. public economics and 
macroeconomics (Demirbas, 1999). In the case of public economics, majority of the studies support the view that public expenditure spending is caused mainly by increased economic growth (Wagner's hypothesis). On the other hand, most investigations in macroeconomics suggest that economic growth is influenced by public expenditure (Keynesian hypothesis).

A large number of studies have explored the effects of public expenditure on economic growth with the empirical literature yielding conflicting results. Katrakilidis and Tsaliki (2009) tested the empirical relationship between economic growth and government spending employing data spanning the period 1958-2004 on the Greek economy. They observed a long-run equilibrium relationship between government expenditures and economic output. Furthermore, the analysis detects causal effects in both the short-run and long-run horizon running from government expenditures to the level of economic activity and vice versa. Findings from the ARDL framework used, thus; indicated a-directional causality between income and government expenditures, in support of both the Wagner's law and the Keynesian hypothesis.

It should be recalled that $\mathrm{Wu}$ et al. (2010) employed a panel data set comprising 182 countries for the time frame 1950 to 2004 to re-examine the causal relationship between government expenditure and economic growth. By conducting a panel Granger causality test their study found strong empirical evidence in support of Wagner's law. They argue that government spending was helpful to economic growth regardless of how they measure the government size and economic growth. When the countries were disaggregated by income levels and the degree of corruption, their results also confirm the bi-directional causality between government activities and economic growth for the different sub-samples of countries, with the exception of the low-income countries. They suggested that the distinct feature of the lowincome countries is likely owing to their inefficient governments and poor quality institutions. 
Chang et al. (2011) employed the definitions of income levels by the World Bank, i.e. high, middle and low and found that public spending is inversely related to economic growth for the panel of low-income countries, with a marginal significance level of $10 \%$. Using data from 23 Organization of Economic Cooperation and Development (OECD) countries, Lamartina and Zaghini (2011) employed panel cointegration analysis to examine government expenditure and economic growth. The authors reported a structural positive correlation between public spending and per-capita gross domestic product (GDP), which they observed was consistent with the socalled Wagner's law. This correlation was reported as being usually higher in countries with lower per-capita GDP.

Reappraising the two contending theories purporting to explain long-run government spending, i.e. Wagner's Law and different variants of the ratchet effect, Durevall and Henrekson (2011) analysed data on Sweden and the United Kingdom spanning the early 19th century until 2010. In contrast to previous studies, they evaluated the validity of Wagner's Law and the ratchet effect hypothesis over a very long time period. Cointegration analysis was used to investigate the long-run relationships between government expenditure and GDP, focusing on sub-periods and structural breaks. Moreover, they tested the ratchet effect hypothesis by estimating models which allow for asymmetric adjustment. According to their main results, Wagner's law does not hold in the long run, although the data was consistent with Wagner's Law between roughly 1860 and the mid-1970s. They noted that this can be traced to the formation of the modern public sector, including the introduction of public education, health care, among other factors. Yet Wagner's Law did not hold during the initial industrialization phase (before 1860), and in recent periods GDP only affects the government spending share when they control for population and age structure. Finally, they found some evidence of asymmetric adjustment in the UK, particularly in 
the post-World War II period. However, the ratchet effect is not a general cause of the growth of government spending.

Moreover, Chang et al. (2011) applied the Generalized Method of Moments (GMM) on a panel of 90 countries spanning over 1992-2006. They explored possible relationships between military expenditure and economic growth, based on the definitions of income levels by the World Bank, i.e. high, middle and low. Their results indicate that military spending leads negatively to economic growth for the panels of low income countries with a marginal significance level of $10 \%$. Of four different regional panels (Africa, Europe, the Middle EastSouth Asia and Pacific Rim), a negative but stronger (5\% significance level) causal relationship from military expenditure to economic growth is found for the Europe and Middle East-South Asian regions.

Meanwhile, Wang (2011) used total health care expenditure data for 31 countries from 1986 to 2007 for exploring the causality between an increase in health care expenditure and economic growth. The empirical procedure is divided into two parts. The first is the panel regression analysis and the second is the quantile regression analysis. The estimation of the panel regression reveals that, expenditure growth stimulates economic growth; however, economic growth reduces expenditure growth. With regard to the estimation of quantile regression, when economic growth is quantile, in countries with low level of growth, the influence of expenditure growth on economic growth is different. In countries with medium and high levels of economic growth, the influence of expenditure growth on economic growth is positive; when health care expenditure growth is quantile, the influence of economic growth on expenditure growth indicates a higher difference. 
Moreover, Wahab (2011) investigated the effects of aggregate and disaggregate government spending variables on output growth. Both cross-section and panel regression estimations were conducted using a model that accommodates asymmetric adjustments of output growth to changes in growth of government spending. He found that aggregate government spending appears to have positive output growth effects particularly in periods of below-trend growth. The government sector's productivity appears to be higher than non-government sector's productivity when spending growth is below-trend growth and only for the non-OECD (Organisation for Economic Cooperation and Development) countries. No differences in sectoral productivities are detected for OECD countries. The author observed that government consumption spending has no significant output growth effects, but government investment spending had positive output growth effects particularly when its growth falls below its trend-growth; this favourable effect turns negative when government investment spending growth exceeds its trend-growth.

Furthermore, Harun et al. (2012) empirically explored the impact of public expenditure expansion in reducing inter-ethnic and rural-urban income disparity. They examined the impact within the context of a Social Accounting Matrix (SAM) based fixed price multiplier model. Generally their results show that public expenditure expansion has improved income inequality in Malaysia. The public expenditure expansion significantly improved the distribution of income across different household groups where it reduced both the Malay-Chinese and Malay-Indian income inequality as well as reduced income disparity between rural and urban areas. On the other hand, Narayan et al. (2012) tested the Wagner's law for 15 Indian states. They considered nine panels of states based on geography and level of economic development. Using panel unitroot, panel-cointegration, and panel-Granger causality analysis, they found strong evidence of 
Wagner's law. However, they found that the Wagner's law relationship is consumption rather than capital-expenditure driven.

It should be recalled that $\mathrm{Wu}$ and Lin (2012) investigated the determinants of government size at the provincial level in China. Employing panel data model their study shows that Wagner's law does not hold true for China. Moreover, both expenditure decentralization and revenue decentralization contribute to the expansion of China's government. In addition they find that openness to trade and foreign direct investment (FDI) limit government expansion, and that the provincial-level public sector is characterized by economies of scale. Brückner et al. (2012) provided instrumental variable estimates of the permanent income elasticity of government expenditures. They employed annual variation in the international oil price weighted with countries' average oil net-export GDP shares as a plausibly exogenous source of within-country variation in countries' permanent income. The short-run estimates of the permanent income elasticity are robust across alternative specifications and are below one: the estimated elasticity coefficients range between 0.3 and 0.6 and have standard errors of 0.1 and 0.4 , respectively. Point estimates of long-run elasticities are somewhat larger but still smaller than unity. They found that investment component of government spending is found to be more elastic than the consumption component, whereas elasticity differences between rich and poor countries are insignificant.

It should be noted that Mihaiu and Opreana (2013) examined if public expenditure for development have a decisive role in Romania in the economic recovery of the country, in a first step, but at the same time taking into account the European Union's objectives. They observed that Romania during 2000-2010 had the largest public investment expenditures across European countries as a share of GDP, and in 2011 and was ranked second after Poland. But while the 
share of GDP allocated to public investment in Romania was above the average of EU countries, in the economy these expenditures have been seen too little. Looking at the Lisbon Index score, which tracks the performance of member countries to achieve the objectives of the current Lisbon strategy, one can notice that Romania is on the penultimate position, being preceded only by Bulgaria. The explanation for this poor performance in achieving the objectives of development comes from the lack of efficiency with which public money was used in financing investment projects and the low absorption rate of EU funds; Romania recorded in 2013 a rate of absorption of structural and cohesion funds of only $13.05 \%$, the lowest among Central and Eastern Europe (CEE) countries.

Moreover, using the time series data during the period 1980-2010 for Pakistan, Attari and Javed (2013) explored the relationship between economic growth and government expenditure among others in case of Pakistan. Disaggregating the government expenditure into the government current expenditure and the government development expenditure, the authors find a long term relationship between economic growth and government expenditure. The authors argue that government expenditure yield positive externalities and linkages. Even in the short run, the authors observed that government expenditures do affect economic growth. The causality test demonstrated a unidirectional causation between economic growth and government expenditure.

Besides, Oktayer and Oktaye (2013) tested the validity of Wagner's law on the Turkish economy using the Autoregressive Distributed lag (ARDL) cointegration technique over 19502010 period. While no long-run relationship between the variables were found in the bivariate (first step) of the testing procedure, a long-run correlation was found in the second step when a 
trivariate framework incorporation inflation rate was employed. Moreover, non-interest government expenditure was used instead of total government expenditures.

Turning to a component of public expenditure, Arze et al. (2013) studied the cyclical behaviour of public spending on health and education in 145 countries during 1987-2007. They found that spending on education and health is procyclical in developing countries and a cyclical in developed countries. In addition, education and health expenditures follow an asymmetric pattern in developing countries. He observed that they are procyclical during periods of positive output gap and a cyclical during periods of negative output gap. Furthermore, the degree of cyclicality is higher the lower the level of economic development. Further, Menyah and WoldeRufael (2013) investigated the relationship between government expenditure and economic growth in Ethiopia. Using the bounds test approach to cointegration, the paper found robust evidence of a long-run relationship between government expenditure and national income.

Furthermore, on components of public expenditure and its influence on growth, Chen et al. (2014) applied a two-step GMM to re-examine the causality between defence expenditure and growth for 137 countries. Their findings indicate that in the lower-middle- and high-income countries a short-run causality running from defence burden to growth was evident and that of the low income countries, while bidirectional short-run causality is found in Asia, Europe, Latin America \& the Caribbean and the Middle East and North Africa. No causality was found in upper-middle-income, European and Central Asian and Sub-Saharan African countries.

In this note Bayrak and Esen (2014) found both short- and long-run relationship between public expenditures and economic growth, using data on 27 OECD economies between the years 1995 and 2012. In this respect, Afonso and Jalles (2014) used a panel dataset of 155 developed and developing countries for the period 1970-2010 to examine the validity or otherwise of the 
Wagner's law. A causal link was found from government expenditures to per capita GDP, consistent with the Wagner's law.

It should be recalled that Ogbonna (2015) examined the plausibility of Wagner's law for Greece for the period 1948 - 2010. Using causality tests, the results indicate that there is no evidence to support either the Wagner's Law or the alternative Keynesian hypothesis for the Greek economy. Moreover, the Johansen Maximum Likelihood co-integration test and LSEM indicate that the Wagner's law is not supported for Greece.

In a study on Palestine, Abu-Eideh (2015)_found a_long-run relationship between public expenditure and GDP growth. In addition and using the Granger causality framework, both public expenditure and GDP were found to have a feedback relationship. Wagner's Law was thus validated for Palestine as both public expenditure and GDP were found to grow substantially.

Additionally, Masan (2015) investigated the relationship between GDP and total as well as disaggregated public expenditures in Oman over the period 1980-2005. Using the EngleGranger's two-step cointegration and Granger Causality techniques, most of the results do not show evidence of long-run equilibrium between government expenditures and national income, but they support the short-run unidirectional causality from economic growth to government expenditures, implying that a rise in the level of national income may be a cause in the growth of government expenditure, in line with the Wagner's Law.

Likewise, Magazzino et al. (2015) studied the relationship between real GDP and GGE, total current expenditure and investment expenditure for $27 \mathrm{EU}$ member countries, using annual data for the period 1980- 2013. The empirical results suggest that there is a long-run relationship among the variables. The results of the Granger causality tests were however mixed, and the 
authors concluded that the relationship between the three items of government expenditure and national income used in the study appear to be more Wagnerian than Keynesian.

Further, Keho (2015) examined the causal relationship between government expenditure and economic growth and tested the validity of Wagner's Law for tenth African countries. Using the Granger causality tests in the frequency domain which allows short, medium and long run causality to be distinguished, the results indicate that Wagner's law holds for Cameroon only in the medium term, for Ghana in the short, medium and long terms and for Nigeria in the long-run. The opposite results were found for Gabon and Senegal in the short, medium and long run, and for South Africa in the medium and short run. For Burkina Faso, bidirectional causality was found between government expenditure and income over the short, medium and long run.

Besides, Ahmad and Suleiman (2015), investigated the link between government spending and economic growth on Nigeria between 1972 and 2011, using the Autoregressive Distributed Lag testing, combined with Toda-Yamamoto non- Granger causality test. The empirical results indicate that there is cointegration in both methods employed, while the causality test results are supportive of the Wagner' Law.

It should be noted that Bayu (2015) investigated the nexus between economic growth and government expenditure for the Ethiopian economy, using annual data from 1974 to 2009 and the Engel-Granger cointegration technique. The result shows that only the Peacock and Wiseman (1961) version of Wagner's law is supported. Moreover, a unidirectional causality was found to run from economic growth to government consumption expenditure.

Further, Keho (2016) examined the relationship between government expenditure and national income for sixth African countries over the period from 1960 to 2013. Using the Gregory and Hansen (1996) cointegration test which allows for a structural break in the long run 
relationships, evidence of Wagner's law was found for Ghana over the period 1960-2013 and in Cote d'Ivoire for the period 1960-1995. For Kenya, in the period 1960-1991, both the Wagner's law and Keynesian hypotheses were supported. The results for the other three countries (namely Benin, Senegal and South Africa) do not support either the Wagner's law or the alternative Keynesian hypothesis in the long run.

Finally, Thabane and Lebina (2016) examined the long-run and causal relationship between government spending and economic growth in Lesotho using the ARDL bounds testing procedure for the period 1980 to 2012 and found a stable long-term relationship between government spending and economic growth. In addition, a bidirectional causality running from economic growth to government expenditure was found, confirming Wagner's Law.

\section{Methodology}

This section demonstrates the data sources and model and estimation procedures employed in this study as followings.

\subsection{Sources of Data}

The data used are annual comprising real gross domestic product per capita, nominal gross domestic product, real government expenditure and nominal government expenditure per capita. The study covers a period of 2005 to 2014. Ten countries were selected in Sub-Saharan Africa and studied. The data are from the World Development Indicators (World Bank, 2014), and the World Economic Outlook (IMF, 2014). 


\subsection{Model Specification and Estimation Procedures}

We investigate the validity of the Wagner's law in Sub-Saharan Africa on five versions in the literature, namely the Peacock-Wiseman (1961), Gupta (1967), Goffman (1968), Musgrave (1969), and the Mann (1980) versions respectively. These models are specified as follows:

$$
\begin{aligned}
& G E_{t}=\alpha_{0}+\alpha_{1} G D P+e_{t} \\
& \left(\frac{G E}{P}\right)_{t}=\beta_{0}+\beta_{1}\left(\frac{G D P}{P}\right)_{t}+e_{t} \\
& G E_{t}=\phi_{0}+\phi_{1}\left(\frac{G D P}{P}\right)_{t}+e_{t} \\
& \left(\frac{G E}{G D P}\right)_{t}=\lambda_{0}+\lambda_{1}\left(\frac{G D P}{P}\right)_{t}+e_{t} \\
& \left(\frac{G E}{G D P}\right)_{t}=\Psi_{0}+\Psi_{1} G D P_{t}+e_{t}
\end{aligned}
$$

where GE is the log of real government expenditures, $\mathrm{P}$ is $\log$ of population, (GE/GDP) is the $\log$ of the share of government spending in total output, GDP/P is the log of the per capita real output, GE/P is the log of the per capita real government expenditures, GDP is the log of real GDP.

The literature on public expenditure and growth is largely of an empirical nature and the link between public expenditure and economic growth remains an empirical question. Being aware of this lack of clear theoretical predictions, in this thesis we turn to the data on the sub-Saharan 
African countries bearing in mind the findings of the past studies and the research gaps identified.

Important changes have occurred in the last three decades on the methods of estimating economic relationships and modelling. The Ordinary Least Squares (OLS) method, which is the standard regression model, is based on the assumption that the stochastic properties of the variables are stationary or time-invariant. The implication therefore of using non-stationary variables in modelling using OLS framework leads to misleading inferences (Glynn et al., 2007). When variables are non-stationary, estimating long-run relationship is based on the method of cointegration. However, before cointegration relationship is established, it is necessary to conduct tests of unit root.

The stability properties of the variables used in the thesis were first examined in order to determine their order of integration. This is important as it helps determine the appropriate econometric framework to be adopted for analysis, and helping to avoid the spurious regression phenomenon. It needs to be noted that testing for unit roots in time series studies has become an integral part of econometric studies, while in the case of panel data, it is relatively recent.

Six panel unit root tests were considered in the thesis. These are the Levin, Lin, and Chu (2002), Breitung (2000), Hadri (2000), Im, Pesaran and Shin (2003), Fisher ADF, and Fisher PP (Maddala \& Wu, 1999; Choi, 2001). Thus the unit root tests are subdivided into two, i.e. those with a common or homogenous unit root process and those with processes that are heterogeneous. The need for the two type tests is in keeping with the empirical necessity of investigating the countries in SSA as either homogenous due to their common history of colonialism and similar economic structures; or heterogeneous in terms of different levels of national income. While the first three are tests with common unit root process (homogeneous), 
the latter three relate to individual unit root process (heterogeneous) in the series.

The test for cointegration logically follows that of unit root. To determine the existence or otherwise of a cointegrating relationship in the series used for investigation, the methodology proposed by Pedroni (1999) and Kao (1999) was utilized.

Pedroni (1999) employed four panel statistics and three group panel statistics to test the null hypothesis of no cointegration against the alternative hypothesis of cointegration. In the former case of panel statistics, the first-order autoregressive term is assumed to be the same across all the cross sections, while in the case of group panel statistics, the parameter is allowed to vary over the cross sections. Pedroni's (1999) test allows for considerable heterogeneity, and considers the following type of specification:

$$
y_{i t}=\alpha_{i}+\delta_{i} t+X_{i t}^{\prime} \beta_{i}+e_{i t}
$$

where $\mathrm{y}_{\mathrm{it}}$ and $\mathrm{X}_{\mathrm{it}}$ are time series panel of observations for members $i=1 \ldots, N$ over time periods denoted a $t=1, \ldots, T$. In addition, $X_{i t}$ is an m-dimensional column vector for each member $i$ and $\mathrm{P}_{\mathrm{t}}$ is an m-dimensional column vector for each member $i$ in the panel. The variables $y_{i t}$ and $X_{i t}$ are assumed to have a unit root or integrated of order 1 for each member $i$ of the panel.

Important in the test is that the possibility of member specific fixed effects and deterministic trends are allowed in the parameters $\alpha_{i}$ and $\delta_{i}$. The cointegrating vectors may be heterogeneous across members of the panel as the slope coefficient $\beta_{i}$ can vary individually.

The DF-type test is computed from the fixed effects residuals in the following specification:

$$
\hat{e}_{i t}=\rho \hat{e}_{i, t-1}+v_{i t}
$$


The ADF-type tests can be calculated from the fixed effects residuals given as follows:

$$
\hat{e}_{i t}=\rho \hat{e}_{i, t-1}+\sum_{j=1}^{p} \delta_{j} \Delta \hat{e}_{i, t-j}+v_{i t}
$$

Two categories of Pedroni's tests can be identified. The first category relates to what is referred to as within dimension, involving averaging test statistics for cointegration in the time series across cross-section. In the second category referred to as between dimension, the averaging is implemented in pieces. However, both categories have similar basic approach in that the hypothesized cointegration relationship is initially estimated separately for each series of the panel and the resulting residuals are pooled when testing for the null of no cointegration. Pooling the residuals in the second step will follow different patterns among the various statistics, which are defined as follows:

Panel variance ratio statistic:

$$
Z_{\hat{V}_{N T}}=\hat{L}_{11}^{2}\left(\sum_{i=1}^{N} A_{22 i}\right)^{-1}=\hat{L}_{11}^{2}\left(\sum_{i=1}^{N} \sum_{t=1}^{T} e_{i, t-1}^{2}\right)^{-1}
$$

Panel rho-statistic:

$$
Z_{\hat{\rho}_{N T}-1}=\left(\sum_{i=1}^{N} A_{22 i}\right)^{-1}=\left(\sum_{i=1}^{N}\left(A_{22 i}-T \hat{\lambda}_{i}\right)\right)=\left(\sum_{i=1}^{N} \sum_{t=1}^{T} e_{i, t-1}^{2}\right)^{-1}\left[\sum_{i=1}^{N} \sum_{t=1}^{T}\left(\Delta \hat{e}_{i t} \hat{e}_{i, t-1}-\hat{\lambda}_{i}\right)\right]
$$


Panel t-statistic:

$$
Z_{\hat{t}_{N T}-1}=\left(\tilde{\sigma}_{N T}^{2} \sum_{i=1}^{N} A_{22 i}\right)^{-\frac{1}{2}}\left[\sum_{i=1}^{N}\left(A_{21 i}-T \hat{\lambda}_{i}\right)\right]=\left(\tilde{\sigma}_{N T}^{2} \sum_{i=1}^{N} \sum_{t=1}^{T} e_{i, t-1}^{2}\right)^{-\frac{1}{2}}\left[\sum_{i=1}^{N} \sum_{t=1}^{T}\left(\Delta \hat{e}_{i t} \hat{e}_{i, t-1}-\hat{\lambda}_{i}\right)\right]
$$

Group rho-statistic:

$$
\widetilde{Z}_{\hat{\rho}_{N T}-1}=\sum_{i=1}^{N} A_{22 i}^{-1}\left(A_{22 i}-T \hat{\lambda}_{i}\right)=\sum_{i=1}^{N}\left[\left(\sum_{i=1}^{N} e_{i, t-1}^{2}\right)^{-1} \sum_{t=1}^{T}\left(\Delta \hat{e}_{i t} \hat{e}_{i, t-1}-\hat{\lambda}_{i}\right)\right]
$$

Group t-statistic:

$$
\tilde{Z}_{\hat{t}_{N T}-1}=\sum_{i=1}^{N}\left[\left(\hat{\sigma}_{i}^{2} \sum_{t=1}^{T} e_{i, t-1}^{2}\right)^{-\frac{1}{2}}\right]\left[\sum_{t=1}^{T}\left(\Delta \hat{e}_{i t} \hat{e}_{i, t-1}-\hat{\lambda}_{i}\right)\right]
$$

From the above statistic, the following are defined:

$$
\begin{aligned}
& \hat{\mu}_{i t}=\hat{e}_{i t}-\hat{\rho}_{i} \hat{e}_{i, t-1} ; \hat{\lambda}_{i}=\frac{1}{T} \sum_{s=1}^{K_{i}} w_{s K_{i}} \sum_{t=s+1}^{T} \hat{\mu}_{i t} \hat{\mu}_{i, t-s} ; w_{s K_{i}}=1-\frac{s}{1+K_{i}} ; \\
& \hat{S}_{i}^{2}=\frac{1}{T} \sum_{t=1}^{T} \hat{\mu}_{i t}^{2} ; \hat{\sigma}_{i}^{2}=\hat{S}_{i}^{2}+2 \hat{\lambda}_{i}^{2} ; \hat{\sigma}_{N T}^{2}=\frac{1}{N} \sum_{t=1}^{N} \hat{\sigma}_{i}^{2} ; \hat{L}_{11}^{2}=\frac{1}{N} \sum_{t=1}^{N} \hat{L}_{11 i}^{2}
\end{aligned}
$$


where $\hat{L}_{11 i}=\left(\hat{\Pi}_{11 i}-\hat{\Pi}_{21 i}^{\prime}-\hat{\Pi}_{22 i}^{-1} \hat{\Pi}_{21 i}\right)^{1 / 2}$ and $\hat{\Pi}_{i}$ is a consistent estimator of $\Pi_{i}$.

Two tests of cointegration in panel were devised by Kao (1999). It starts by considering the panel regression model of the form:

$$
y_{i t}=x_{i t}^{\prime} \beta+z_{i t}^{\prime} \gamma+e_{i t}
$$

where the variables $y_{i t}$ and $x_{i t}$ have a unit root or $I(1)$ and noncointegrated. For $e_{t}$ as a test for the null of no cointegration, Kao (1999) proposed DF and ADF-type unit root tests, with the DFtype tests computed from the fixed effects residuals:

$$
\hat{e}_{i t}=\rho \hat{e}_{i, t-1}+v_{i t}
$$

Using OLS, $p$ and $t$ can be computed with the following specifications:

$$
\hat{\rho}=\frac{\sum_{i=1}^{N} \sum_{i=2}^{T} \hat{e}_{i t} \hat{e}_{i, t-1}}{\sum_{i=1}^{N} \sum_{i=2}^{T} \hat{e}_{i t}^{2}}
$$




$$
t_{\rho}=\frac{(\hat{\rho}-1) \sqrt{\sum_{i=1}^{N} \sum_{i=2}^{T} \hat{e}_{i, t-1}^{2}}}{S_{e}}, \text { where } S_{e}^{2}=\frac{1}{N T} \sum_{i=1}^{N} \sum_{i=2}^{T}\left(\hat{e}_{i t}-\hat{\rho} \hat{e}_{i, t-1}\right)^{2}
$$

The four type DF tests are given by:

$$
\begin{gathered}
D F_{\rho}=\frac{\sqrt{N T}(\hat{\rho}-1)+3 \sqrt{N}}{\sqrt{10.2}} \\
D F_{t}=\sqrt{1.25 . t_{\rho}+\sqrt{1.875 N}} \\
D F_{\rho}^{*}=\frac{\sqrt{N T}(\hat{\rho}-1)+\frac{3 \sqrt{N} \hat{\sigma}_{v}^{2}}{\hat{\sigma}_{o v}^{2}}}{\sqrt{3+\frac{36 \hat{\sigma}_{o v}^{4}}{5 \hat{\sigma}_{o v}^{4}}}} \\
D F_{t}^{*}=\frac{\sqrt{\frac{\hat{\sigma}_{o v}^{2}}{2 \hat{\sigma}_{v}^{2}}+\frac{3 \hat{\sigma}_{v}^{2}}{10 \hat{\sigma}_{o v}^{2}}}}{\sqrt{6 N \hat{\sigma}_{v}}}
\end{gathered}
$$

It needs to be noted that while the $D F_{p}$ and $D F_{t}$ are constructed on the basis of the strong exogeneity of the regressors and disturbance terms for the cointegration, the $D F^{*}{ }_{p}$ and $D F^{*}$ on the other hand, are with endogenous relationship between regressors and error terms. 
The ADF test is based on the following specification:

$$
\hat{e}_{i t}=\rho \hat{e}_{i, t-1}+\sum_{j=1}^{p} \delta_{j} \Delta \hat{e}_{i, t-j}+v_{i t}
$$

The ADF test statistics can be derived from:

$$
A D F=\frac{t_{A D F}+\frac{\sqrt{6 N} \hat{\sigma}_{v}}{2 \hat{\sigma}_{o v}}}{\sqrt{\frac{\hat{\sigma}_{o v}^{2}}{2 \hat{\sigma}_{v}^{2}}+\frac{3 \hat{\sigma}_{v}^{2}}{10 \hat{\sigma}_{o v}^{2}}}}
$$

where $t_{A D F}$ is the t-statistic of $p$ in equation (3i)

When evidence of cointegration was found, the next stage in the analysis was to investigate the short-run and long-run causality between public expenditure and gross domestic product through the Error Correction Model (ECM). It needs to be pointed out however that Granger causality tests are applicable regardless of the orders of integration of the underlying variables. However, in implementing the Granger causality test in the presence of a long-run relationship, it is essential to include a lagged error correction term within the error correction model in order to capture the short-run deviations of the series from their long-run relationship (Narayan \& Smyth, 2004).

The ECM specifications of the variables used in the paper are presented in two endogenous variables, i.e. government expenditure and gross domestic product as follows: 


$$
\begin{gathered}
\Delta G E_{i t}=\gamma_{1 i}+\delta_{11} E C M_{t-1}+\sum_{i=1}^{k-1} \delta_{11 i} \Delta G E_{i, t-i}+\sum_{i=1}^{k-1} \delta_{12 i} \Delta G D P_{i, t-i}+\varepsilon_{1 i t} \\
\Delta G D P_{i t}=\gamma_{2 i}+\delta_{21} E C M_{i, t-1}+\sum_{i=1}^{k-1} \delta_{21 i} \Delta G E_{i, t-i}+\sum_{i=1}^{k-1} \delta_{22 i} \Delta G D P_{i, t-i}+\varepsilon_{2 i t}
\end{gathered}
$$

The intercept terms are denoted by $\gamma_{1} \ldots \gamma_{2}$ while the disturbance terms are denoted by $\varepsilon_{1 \mathrm{it}}, \ldots \varepsilon_{2 \mathrm{it}}$. Note that both government expenditure (GE) and gross domestic product (GDP) are presented according to their definitions in the various versions of Wagner's law as captured in equations 1a through 1e.

It is imperative to select the appropriate lag-length in the ECM. This is because the size of the test is adversely affected when selecting too few lags, while the power of the test is reduced when too many lags are used, thereby truncating the degree of freedom (Banerjee et al., 1993). There are several lag length selection criteria in the literature such as the Final prediction error, Akaike information criterion (AIC), Schwarz information criterion (SC), and HannanQuinn information criterion (HQ).

The likelihood ratio (LR) test and the Akaike Information Criterion (AIC) are quite popular in empirical research. A major advantage of the use of the LR test is that it facilitates cross-equation restrictions to test shorter lags versus longer lags. AIC is relatively better than say the Schwartz Bayesian Criterion (SBC) when selecting lags for models that the true data generating process is one of long lags (Ozcicek \& McMillin, 1999). Consequently, the optimal lag length employed in the study was based on AIC and LR. 
There are two sources of causation in an ECM framework i.e. one originating from the ECM term and the other from the lagged dynamic terms. Consequently, two causality tests was carried out, i.e. the short-run Granger non-causality test and the long-run causality. All the causality tests will be executed through the Wald test. To test for long-run non-causality, the null hypothesis that the coefficient of $\mathrm{ECM}_{\mathrm{t}-1}$ is zero is tested in each of the equations (3.40) through (3.41), to determine whether the variables on the right-hand side Granger-cause the variable on the left-hand side.

\section{Results}

This section interprets the results generated from the aforementioned data and models to empirically tell the tale of the countries under study.

\subsection{Cointegration Test Results}

We present the results of the tests for cointegration in Table 1. Results of the unit root tests indicate that the series used are integrated of order 1 . They are not presented for reason of space.

\section{Table 1: Cointegration Test Results}

Panel 1: Pedroni and Kao tests

\begin{tabular}{cccc}
\hline Model & Statistic & Pedroni & Kao \\
\hline \multirow{2}{*}{ Peacock-Wiseman } & Panel PP-Statistic & $-4.776667^{*}$ & - \\
& Panel ADF-Statistic & $-4.574716^{*}$ & -0.189153 \\
\hline
\end{tabular}




\section{Panel PP-Statistic $\quad-2.837851^{*}$}

Gupta
Panel ADF-Statistic
$-1.398397^{* * * *}$
$-0.803165$

\begin{tabular}{lllc}
\hline Goffman & Panel PP-Statistic & $-2.844776^{*}$ & - \\
& Panel ADF-Statistic & $-1.467450^{* *}$ & 0.068700 \\
\hline \multirow{2}{*}{ Musgrave } & Panel PP-Statistic & $-13.40764^{*}$ & - \\
& Panel ADF-Statistic & $-14.87286^{*}$ & $2.771735^{*}$ \\
\hline \multirow{2}{*}{ Mann } & Panel PP-Statistic & 0.931506 & - \\
& Panel ADF-Statistic & $-7.049580^{*}$ & $3.369985^{*}$ \\
\hline
\end{tabular}

Panel 2: Johansen-Fisher Test

Hypothesized Fisher Stat.

No. of CE(s) (Trace test)
Fisher Stat.

(Max-eigen

\begin{tabular}{|c|c|c|c|c|c|}
\hline & No. of $\mathrm{CE}(\mathrm{s})$ & (Trace test) & Prob. & test) & Prob. \\
\hline Peacock- & None & 118.9 & 0.0000 & 105.0 & 0.0000 \\
\hline Wiseman & At most 1 & 50.77 & 0.0002 & 50.77 & 0.0002 \\
\hline \multirow[t]{2}{*}{$\overline{\text { Gupta }}$} & None & 112.8 & 0.0000 & 97.84 & 0.0000 \\
\hline & At most 1 & 47.64 & 0.0005 & 47.64 & 0.0005 \\
\hline \multirow[t]{2}{*}{ Goffman } & None & 104.5 & 0.0000 & 81.84 & 0.0000 \\
\hline & At most 1 & 59.84 & 0.0000 & 59.84 & 0.0000 \\
\hline \multirow[t]{2}{*}{ Musgrave } & None & 103.2 & 0.0000 & 89.28 & 0.0000 \\
\hline & At most 1 & 50.22 & 0.0002 & 50.22 & 0.0002 \\
\hline$\overline{\text { Mann }}$ & None & 108.0 & 0.0000 & 96.37 & 0.0000 \\
\hline
\end{tabular}




$\begin{array}{lllll}\text { At most } 1 & 47.10 & 0.0006 & 47.10 & 0.0006\end{array}$

Panel 3: Johansen Fisher Cointegration Test (Individual cross section results)

Max-Eign

Trace Test Test

Cross Section Statistics Prob. Statistics Prob.

Model Hypothesis of no cointegration

\begin{tabular}{llrrrr}
\hline & Botswana & 12.5408 & 0.1328 & 12.3959 & 0.0967 \\
& Equatorial Guinea & 27.7506 & 0.0005 & 27.0204 & 0.0003 \\
& Mauritania & 14.8372 & 0.0626 & 9.9271 & 0.2168 \\
PEACOCK- & Nigeria & 22.9489 & 0.0031 & 20.7759 & 0.0041 \\
& South Africa & 31.6958 & 0.0001 & 23.2354 & 0.0015 \\
& Sierra Leone & 52.2025 & 0.0000 & 50.8534 & 0.0000 \\
& Tanzania & 5.0824 & 0.8000 & 4.4707 & 0.8066 \\
& Ethiopia & 6.2085 & 0.6709 & 4.9745 & 0.7451 \\
& Madagascar & 27.6728 & 0.0005 & 24.6932 & 0.0008 \\
& DR Congo & 27.1898 & 0.0006 & 16.4563 & 0.0222 \\
& & & & & \\
\hline
\end{tabular}




\begin{tabular}{|c|c|c|c|c|c|}
\hline & Botswana & 13.5064 & 0.0975 & 12.9402 & 0.0801 \\
\hline & Equatorial Guinea & 31.0262 & 0.0001 & 30.8272 & 0.0001 \\
\hline & Mauritania & 14.2646 & 0.0760 & 10.4241 & 0.1855 \\
\hline & Nigeria & 23.5923 & 0.0024 & 20.4092 & 0.0047 \\
\hline \multirow[t]{10}{*}{ GUPTA } & South Africa & 37.4487 & 0.0000 & 24.9074 & 0.0007 \\
\hline & Sierra Leone & 39.6522 & 0.0000 & 39.1901 & 0.0000 \\
\hline & Tanzania & 4.5722 & 0.8525 & 4.3123 & 0.8250 \\
\hline & Ethiopia & 6.0520 & 0.6894 & 5.0175 & 0.7396 \\
\hline & Madagascar & 16.7974 & 0.0317 & 16.6243 & 0.0208 \\
\hline & DR Congo & 29.1138 & 0.0003 & 19.1877 & 0.0077 \\
\hline & Botswana & 13.9867 & 0.0833 & 13.5324 & 0.0650 \\
\hline & Equatorial Guinea & 25.3770 & 0.0012 & 24.9615 & 0.0007 \\
\hline & Mauritania & 14.2262 & 0.0769 & 10.1798 & 0.2004 \\
\hline & Nigeria & 24.3301 & 0.0018 & 20.8281 & 0.0040 \\
\hline \multirow[t]{8}{*}{ GOFFMAN } & South Africa & 33.5525 & 0.0000 & 24.6790 & 0.0008 \\
\hline & Sierra Leone & 24.2333 & 0.0019 & 23.1518 & 0.0015 \\
\hline & Tanzania & 5.3755 & 0.7677 & 4.9790 & 0.7445 \\
\hline & Ethiopia & 5.9856 & 0.6972 & 5.0125 & 0.7402 \\
\hline & Madagascar & 26.4339 & 0.0008 & 17.3553 & 0.0157 \\
\hline & DR Congo & 33.4444 & 0.0000 & 20.7941 & 0.0040 \\
\hline & Botswana & 14.4746 & 0.0708 & 12.6107 & 0.0898 \\
\hline & Equatorial Guinea & 39.7574 & 0.0000 & 34.9212 & 0.0000 \\
\hline
\end{tabular}




\begin{tabular}{|c|c|c|c|c|c|}
\hline & Mauritania & 20.3226 & 0.0086 & 17.2812 & 0.0162 \\
\hline & Nigeria & 12.7010 & 0.1262 & 12.6343 & 0.0890 \\
\hline & South Africa & 31.6563 & 0.0001 & 25.8414 & 0.0005 \\
\hline MUSGRAVE & Sierra Leone & 10.6004 & 0.2373 & 6.0799 & 0.6030 \\
\hline & Tanzania & 6.5348 & 0.6323 & 6.5309 & 0.5460 \\
\hline & Ethiopia & 32.2137 & 0.0001 & 30.1964 & 0.0001 \\
\hline & Madagascar & 20.5715 & 0.0079 & 12.0472 & 0.1089 \\
\hline & DR Congo & 18.6600 & 0.0161 & 16.5431 & 0.0214 \\
\hline & Botswana & 14.3058 & 0.0749 & 12.3416 & 0.0985 \\
\hline & Equatorial Guinea & 42.8740 & 0.0000 & 33.7822 & 0.0000 \\
\hline & Mauritania & 20.4274 & 0.0083 & 17.6031 & 0.0143 \\
\hline & Nigeria & 12.5459 & 0.1326 & 12.5436 & 0.0919 \\
\hline MANN & South Africa & 24.7377 & 0.0015 & 20.5290 & 0.0045 \\
\hline & Sierra Leone & 11.8240 & 0.1656 & 7.1111 & 0.4761 \\
\hline & Tanzania & 7.0927 & 0.5669 & 7.0377 & 0.4847 \\
\hline & Ethiopia & 31.6602 & 0.0001 & 29.3251 & 0.0001 \\
\hline & Madagascar & 29.1146 & 0.0003 & 27.2777 & 0.0003 \\
\hline & DR Congo & 20.0499 & 0.0096 & 16.8556 & 0.0190 \\
\hline
\end{tabular}

Source: Authors' computations

The Pedroni cointegration test results are presented in Panel 1 of Table 1. The null hypothesis of no cointegration is rejected in all the versions of Wagner's models, as evidenced by the statistical significance of the Panel PP and ADF statistics respectively. 
The results of the Kao cointegration tests present somewhat different results. Whereas the null of no cointegration is accepted for the Peacock-Wiseman, Gupta and Goffman's versions of Wagner's law, the reverse is the case with the Musgrave and Mann versions respectively. Overall, it is plausible to conclude that, irrespective of the version of the Wagner's law tested, the empirical results suggest that there is a long-run equilibrium relationship between government expenditure and economic growth. This conclusion is corroborated by the results in Panel 3 of Table 1, where individual cross section results are presented. In majority of cases, the null hypothesis of no cointegration is rejected. Specifically, in the Peacock-Wiseman version of Wagner's law, results for Mauritania, Tanzania and Ethiopia accept the null of no cointegration. It is the same with the Gupta and Goffman versions. In the case of the Musgrave's and Mann's versions, only the results of Sierra Leone and Tanzania indicate presence of no cointegration. The overwhelming empirical evidence therefore is that there exists a long-run equilibrium relationship between government expenditure and economic growth in a panel of setting for the 10 selected countries in Sub-Saharan Africa.

For robustness, the ten selected countries used in the study were divided into two group namely higher and lower income groups respectively in line with World Bank income classification. Countries in the higher income group are Botswana, Equatorial Guinea, Mauritius, Nigeria and South Africa; while in the lower income countries encompass Sierra Leone, Tanzania, Ethiopia, Madagascar and DR Congo. Cointegration tests were consequently applied to each group. The results of the cointegration tests for each of the two groups of countries are presented in Appendices 1 and 2 and are not discussed to conserve space. However, the results are conclusive of a long run equilibrium relationship between public expenditure and income across the countries studied. 


\subsection{Causality Test Results}

The long-run causality test results in respect of all the selected countries used in the investigation are presented in 2. Because causality tests are sensitive to lag length, we first fit a vector autoregressive (VAR) regression for each of the models and tested for the optimal lags. The results of the lag length selection criteria are presented in the Appendix 1.

Table 2: Causality Tests (All selected countries)

\begin{tabular}{|c|c|c|c|}
\hline Version of & Hypothesis & LR-causality & Conclusion \\
\hline \multicolumn{4}{|l|}{ Wagner's law } \\
\hline \multirow[t]{3}{*}{ Peacock-Wiseman } & Ho: $\Delta \mathrm{GDP} \nrightarrow \Delta \mathrm{GE}$ & $2.52400^{* * * *}(3)$ & Keynesian and \\
\hline & $\Delta \mathrm{GE} \nrightarrow \Delta \mathrm{GDP}$ & $7.78030(1)^{*}$ & Wagners laws \\
\hline & & & hold \\
\hline \multirow[t]{2}{*}{ Gupta } & Ho: $\Delta \mathrm{GDP} / \mathrm{P} \nrightarrow \Delta \mathrm{GE} / \mathrm{P}$ & 1.75910 & Keynesian law \\
\hline & $\Delta \mathrm{GE} / \mathrm{P} \nrightarrow \Delta \mathrm{GDP} / \mathrm{P}$ & $7.77728(8)^{* * *}$ & holds \\
\hline \multirow[t]{2}{*}{ Goffman } & Ho: $\Delta \mathrm{GDP} / \mathrm{P} \nrightarrow \Delta \mathrm{GE}$ & $2.53410(3)^{* * *}$ & Wagners law \\
\hline & $\Delta \mathrm{GE} \nrightarrow \Delta \mathrm{GDP} / \mathrm{P}$ & 0.35968 & holds \\
\hline Musgrave & Ho: $\Delta \mathrm{GDP} / \mathrm{P} \nrightarrow \Delta \mathrm{GE} / \mathrm{GDP}$ & $2.16418(6)^{* * * *}$ & Keynesian and \\
\hline
\end{tabular}




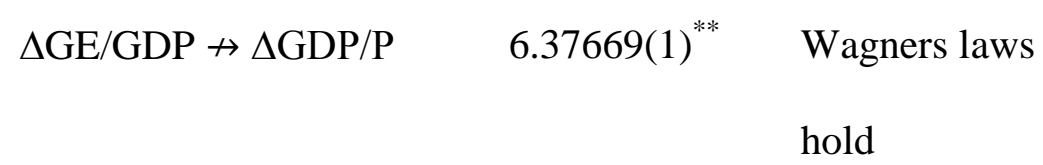

\begin{tabular}{|c|c|c|c|}
\hline \multirow[t]{2}{*}{ Mann } & Ho: $\Delta \mathrm{GDP} \nrightarrow \Delta \mathrm{GE} / \mathrm{GDP}$ & $2.36241(5)^{* * * *}$ & Keynesian and \\
\hline & $\Delta \mathrm{GE} / \mathrm{GDP} \nrightarrow \Delta \mathrm{GDP}$ & $2.99511(1)^{* * *}$ & Wagners laws \\
\hline & & & hold \\
\hline
\end{tabular}

Note: $\nrightarrow$ denotes "does not Granger-Cause. Number in parenthesis denotes lags used. ${ }^{*}$, and ${ }^{* * *}$ denote rejection of the null hypothesis at $1 \%, 5 \%$ and $10 \%$ level of significance respectively.

Source: Authors' computations

From the empirical results in Table 2, the long-run causality tests indicate that there is bidirectional causality between expenditure and income in all models with the exemption of the Gupta model. In other words, both the Wagner's and the competing Keynesian hypothesis are valid for the selected countries in sub-Saharan Africa.

In the Gupta version, causality flows for expenditure to income, supporting the Keynesian assertion of the significance of government expenditure in economic growth. On the whole, the conclusion that can be reached is that in Sub-Saharan Africa, both the Wagner's law and the Keynesian hypothesis tend to be valid.

\section{Conclusion And Implications}


This paper empirically analyses public expenditure and economic growth, with emphasis on $10^{\text {th }}$ (tenth) selected countries in sub-Saharan Africa. Using five acknowledged models in the empirical literature, we tested for cointegration and causality, having first established the order of integration of the variables employed. These models follow the framework of PeacockWiseman (1961), Gupta (1967), Goffman (1968), Musgrave (1969) and Mann (1980).

The study found a long run relationship between the public expenditure and the various explanatory variables used as proxies of income in line with the variant of real income used in the models.

The empirical results are supportive of the conclusion that both the Wagner's Law and the Keynesian hypotheses are valid for the selected countries for the period 2005-2014. In essence, the explanation is that there has been the tendency for public expenditure to grow relative to national income (Wagner's law) and that public expenditure is a policy instrument (an exogenous factor) for improving national income (Keynesian hypothesis) during the 10-year period.

Importantly, the long-run causality tests indicate that there is bidirectional causality between expenditure and income in all modes with the exemption of the Gupta model. In other words, both the Wagner's and the competing Keynesian hypothesis are valid for the selected countries in sub-Saharan Africa. In the Gupta version, causality flows from expenditure to income, supporting the Keynesian assertion of the significance of government expenditure in economic growth. On the whole, the conclusion that can be reached is that in Sub-Saharan Africa, both the Wagner's law the Keynesian hypothesis tend to be valid. 


\section{References}

Abu-Eideh, O.M. (2015). Causality between Public Expenditure and GDP Growth in Palestine: An Econometric Analysis of Wagner's Law. Journal of Economics and Sustainable Development, 6(2), 189-199.

Ahmad, U.G., \& Suleiman, U.A. (2015). Revisiting the link between government spending and economic growth in the present of Wagner's Law in Nigeria. Journal of Economics and Finance, 6(6), 56-64.

Afonso, A., \& Jalles, J.T. (2014). Causality for the government budget and economic growth. Applied Economics Letters, 21(17), 1198-1201.

Albatel, A.H. (2002). Wagner's Law and the Expanding Public Sector in Saudi Arabia. Administrative Sciences, 14 (2), 139-156.

Arze Del Granado, J., Gupta, S., \& HajdenberG, A. (2013). Is Social Spending Procyclical? Evidence for Developing Countries. World Development, 42, 16-27.

Attari, M.I.J., \& Javed, A.Y. (2013). Inflation, Economic Growth and Government Expenditure of Pakistan: 1980-2010. Procedia Economics and Finance 5, 58-67. 
Bayu, T. (2015). Empirical Verification of Wagner's Law in Ethiopia, Journal of Economics and Sustainable Development, 1(1), 140-146.

Bayrak, M. \& Esen, Ö. (2014). Examining the validity of Wagner's law in the OECD Economies. Research in Applied Economics, 6(3), 1-16.

Breitung, J. (2000). The Local Power of Some Unit Root Tests for Panel Data. In Baltagi, B. (ed.),Advances in Econometrics 15: Nonstationary Panels, Panel Cointegration, and Dynamic Panels. Amsterdam: JAI Press, pp. 161-178.

Brückner, M., Chong, A., \& Gradstein, M. (2012). Estimating the permanent income elasticity of government expenditures: Evidence on Wagner's law based on oil price shocks. Journal of Public Economics 96, 1025-1035.

Chang, H.-C., Huang, B.N., \& Yang, C.W. (2011). Military expenditure and economic growth across different groups: A dynamic panel Granger-causality approach. Economic Modelling, $28,2416-2423$.

Chen, P.F., Lee, C.C., \& Chiu, Y.B. (2014). The nexus between defense expenditure and economic growth: New global evidence. Economic Modelling, 36, 474-483.

Choi, I. (2001). Unit Root Tests for Panel Data. Journal of International Money and Finance, 20, 249-272.

Courakis, A.S., Moura-Roque, F., \& Tridimas, G. (1993). Public expenditure growth in Greece and Portugal, Wagner's Law and beyond. Applied Economics, 25, 125-134.

Demirbas, S. (1999). Co-integration Analysis - Causality Testing and Wagner`s Law: The Case of Turkey, 1950-90. Annual Meeting of the European Public Choice Society in Lisbon, April $7-10$. 
Durevall, D., \& Henrekson, M. (2011). The futile quest for a grand explanation of long-run government expenditure. Journal of Public Economics, 95, 708-722.

Goffman, I.J. (1968). On the Empirical Testing of Wagner's Law: A Technical Note. Public Finance, 23, 359-364.

Gupta, S.P. (1967). Public Expenditure and Economic Growth: A Time-Series Analysis. Public Finance 22 (4), 423-461.

Hadri, K. (2000). Testing for Stationarity in Heterogeneous Panel Data. Econometric Journal, 3, $148-161$.

Harun, M., Mat, S.H.C., \& Jalil, A.Z.A. (2012). Public Expenditure Expansion and Inter-ethnic and Rural-urban Income Disparity. Procedia Economics and Finance, 1, 296-303.

Im, K. S., Pesaran, M.H., \& Shin, Y. (2003). Testing for Unit Roots in Heterogeneous Panels. Journal of Econometrics, 115, 53-74.

IMF (2014), Regional Economic Outlook.

Kao, C. (1999). Spurious Regression and Residual-Based Tests for Cointegration in Panel Data. Journal of Econometrics, 90, 1-44.

Katrakilidis, C., \& Tsaliki, P. (2009). Further Evidence on the causal relationship between governemnt spending and economic growth: The case of Greece, 1958-2004. Acta Oeconomica, 59 (1), 57-78.

Keho, Y. (2015). Revisiting Wagner's Law for Selected African Countries: a Frequency Domain Causality Analysis, Journal of Statistical and Econometric Methods 4(4), pp. 55-69.

Keho, Y. (2016). Testing Wagner's Law in the Presence of Structural Changes: New Evidence from Six African Countries (1960-2013). International Journal of Economics and Financial Issues, 6(1), 1-6. 
Lamartina, S., \& Zaghini, A. (2011). Increasing Public Expenditure: Wagner's Law in OECD Countries. German Economic Review, 12, 149-164.

Levin, A., Lin, C.F., \& Chu, C. (2002). Unit Root Tests in Panel Data: Asymptotic and FiniteSample Properties. Journal of Econometrics, 108, 1-24.

Maddala, G.S., \& Wu, S. (1999). A Comparative Study of Unit Root Tests with Panel Data and a New Simple Test. Oxford Bulletin of Economics and Statistics 61, 631-652.

Magazzino, C. (2012). Wagner versus Keynes: Public spending and national income in Italy. Journal of Policy Modeling, 34, 890-905.

Magazzino, C., Giolli, L., \& Mele, M. (2015). Wagner's Law and Peacock and Wiseman's Displacement Effect in European Union Countries: A Panel Data Study. International Journal of Economics and Financial Issues, 5(3), 812-819.

Mann, A.J. (1980). Wagner's law: an econometric test for Mexico, 1925-1976.National Tax Journal, 33 (2), 189-201.

Masan, S.S. (2015). Testing Keynesian versus Wagner Hypothesis on the linkage between Government Spending and Economic Growth in Oman, Proceedings of the Fourth AsiaPacific Conference on Global Business, Economics, Finance and Social Sciences (AP15Malaysia Conference) ISBN - 978-1-63415-762-9 Kuala Lumpur, Malaysia, 7-9 August, 2015 Paper ID: KL553.

Medhi, K. (2014). An Empirical Investigation of the Causality between Government Expenditure and Economic Growth in India during 1974-2010. Journal of Humanities and Social Science $19(7), 53-58$.

Menyah, K., \& Wolde-Rufael, Y. (2013).Government Expenditure and Economic Growth: The Ethiopian Experience, 1950-2007. The Journal of Developing Areas 47, (1), 263-280. 
Mihaiu, D. M., \& Opreana, A. (2013). The Analysis of the Relationship between the Level of the Public Expenditure for Investments and de Degree of Development of the Society in Romania. Procedia Economics and Finance, 6, 654-661.

Narayan, P.K., \&Smyth, R. (2004). The relationship between the real exchange rate and balance of payments: empirical evidence for China from co-integration and causality testing. Applied Economic Letters, 11, 287-291.

Narayan, S., Rath, B. N., \& Narayan, P.K. (2012). Evidence of Wagner's law from Indian states. Economic Modelling, 29, 1548-1557.

Ogbonna, B.C. (2015). Testing for Wagner's Law on Greek Economy. International Journal of Development and Economic Sustainability, 3(5), 26-35.

Oktayer, A., \& Oktaye, N. (2013). Testing Wagner's Law for Turkey: Evidence from A Trivariate Causality Analysis. Prague Economic Papers, 2, 284-301.

Ozcicek, O., \& Mcmillin, W.G. (1999). Lag Length Selection in Vector Autoregressive Models: Symmetric and Asymmetric Lags. Applied Economics, 31 (4), 517-524.

Peacock, A.T., \& Wiseman, J. (1961). The Growth of Public Expenditure in the United Kingdom. Princeton University Press.

Pedroni, P. (1999). Critical Values for Cointegration Tests in Heterogeneous Panels with Multiple Regressors. Oxford Bulletin of Economics and Statistics, 61, 653-670.

Quijano, J.M., \& Garcia, D.R. (2005). Causality and Determinants of Government Spending and Economic Growth: The Philippine Experience 1980-2004.University of Santo Tomas, MetroManila, Philippines.

Thabane, K., \& Lebina, S. (2016). Economic Growth and Government Spending Nexus: Empirical Evidence from Lesotho African Journal of Economic Review, 3(1), 86-100. 
Timm, H., (1961). Das Gesetz der wachsenden Staatsausgaben.Finanzarchiv, 19, 201- 247.

Wagner, A. (1893).Grundlegung der politischen Okonomie, 3rd ed.,Leipzig.

Wahab, M. (2011). Asymmetric output growth effects of government spending: Cross-sectional and panel data evidence. International Review of Economics \& Finance, 20, 574-590.

Wang, K.M. (2011). Health care expenditure and economic growth: Quantile panel-type analysis. Economic Modelling, 28, 1536-1549.

World Bank (2014).World Development Indicators 2014.World Bank, Washington D.C.

Wu, A.M., \& Lin, M. (2012). Determinants of government size: evidence from China. Public Choice, 151, 255-270.

Wu, S.Y., Tang, J.H., \& Lin, E.S. (2010). The impact of government expenditure on economic growth: How sensitive to the level of development? Journal of Policy Modeling 32, 804-817. 


\section{APPENDIX 1}

\section{Cointegration Tests: Selected Higher Income Countries}

Table 1A: Cointegration Tests

Panel Cointegration Test Results (Peacock)

\begin{tabular}{lcc}
\hline & Pedroni & Kao \\
\hline Panel PP-Statistic & $-1.251695^{* * *}$ & - \\
Panel ADF-Statistic & $-5.598451^{* * *}$ & $1.499773^{* * *}$ \\
\hline
\end{tabular}

Source: Author's computations.

Johansen Fisher Panel Cointegration Test (Peacock)

\begin{tabular}{|c|c|c|c|c|}
\hline Hypothesized & $\begin{array}{c}\text { Fisher stat. } \\
\text { (from trace test) }\end{array}$ & Prob. & $\begin{array}{c}\text { Fisher stat. } \\
\text { (from max-eigen } \\
\text { test) }\end{array}$ & Prob. \\
\hline None & 55.12 & 0.0000 & 47.94 & 0.0000 \\
\hline At most 1 & 24.98 & 0.0054 & 24.98 & 0.0054 \\
\hline
\end{tabular}

Individual cross section results

\begin{tabular}{lcccc}
\hline & Trace test & \multicolumn{3}{c}{ Max-eign test } \\
\hline \multicolumn{1}{c}{ Cross section } & Statistics & Prob.** & Statistics & Prob.** \\
\hline Botswana & 12.5408 & 0.1328 & 12.3959 & 0.0967 \\
Equatorial guinea & 27.7506 & 0.0005 & 27.0204 & 0.0003 \\
Mauritania & 14.8372 & 0.0626 & 9.9271 & 0.2168 \\
Nigeria & 22.9489 & 0.0031 & 20.7759 & 0.0041 \\
South africa & 31.6958 & 0.0001 & 23.2354 & 0.0015 \\
\hline
\end{tabular}

Panel Cointegration Test Results (Musgrave) 
Panel PP-Statistic

Pedroni

$-0.493873$

$-1.697314^{* *}$
Kao

$2.751715^{*}$

Johansen Fisher Panel Cointegration Test (Musgrave)

\begin{tabular}{|c|c|c|c|c|}
\hline Hypothesized & $\begin{array}{c}\text { Fisher Stat. } \\
\text { (from trace test) }\end{array}$ & Prob. & $\begin{array}{c}\text { Fisher Stat. } \\
\text { (from max-eigen } \\
\text { test) }\end{array}$ & Prob. \\
\hline None & 62.45 & 0.0000 & 56.03 & 0.0000 \\
\hline At most 1 & 24.44 & 0.0065 & 24.44 & 0.0065 \\
\hline
\end{tabular}

Individual cross section results

\begin{tabular}{lcccc}
\hline & Trace Test & \multicolumn{3}{c}{ Max-Eign Test } \\
\hline \multicolumn{1}{c}{ Cross Section } & Statistics & Prob.** & Statistics & Prob.** \\
\hline Botswana & 14.4746 & 0.0708 & 12.6107 & 0.0898 \\
Equatorial Guinea & 39.7574 & 0.0000 & 34.9212 & 0.0000 \\
Mauritania & 20.3226 & 0.0086 & 17.2812 & 0.0162 \\
Nigeria & 12.7010 & 0.1262 & 12.6343 & 0.0890 \\
South Africa & 31.6563 & 0.0001 & 25.8414 & 0.0005 \\
\hline
\end{tabular}

Panel Cointegration Test Results (Gupta)

\begin{tabular}{lcc}
\hline & Pedroni & Kao \\
\hline Panel PP-Statistic & $-1.358816^{* * * *}$ & - \\
Panel ADF-Statistic & $-4.314105^{*}$ & $-4.417908^{*}$ \\
\hline
\end{tabular}

Johansen Fisher Panel Cointegration Test (Gupta)

\begin{tabular}{ccccc} 
Hypothesized & Fisher Stat. & \multicolumn{3}{c}{$\begin{array}{c}\text { Fisher Stat. } \\
\text { (from max-eigen }\end{array}$} \\
No. of CE(s) & (from trace test) & Prob. & test) & Prob. \\
\hline None & 63.46 & 0.0000 & 52.98 & 0.0000 \\
\hline At most 1 & 29.28 & 0.0011 & 29.28 & 0.0011 \\
\hline
\end{tabular}

Individual cross section results

\begin{tabular}{lcrrr}
\hline & Trace Test & \multicolumn{3}{c}{ Max-Eign Test } \\
\hline \multicolumn{1}{c}{ Cross Section } & Statistics & Prob.** & Statistics & Prob.** \\
\hline Botswana & 13.5064 & 0.0975 & 12.9402 & 0.0801 \\
Equatorial Guinea & 31.0262 & 0.0001 & 30.8272 & 0.0001 \\
Mauritania & 14.2646 & 0.0760 & 10.4241 & 0.1855 \\
Nigeria & 23.5923 & 0.0024 & 20.4092 & 0.0047 \\
South Africa & 37.4487 & 0.0000 & 24.9074 & 0.0007 \\
\hline
\end{tabular}




\section{APPENDIX 2}

\section{Cointegration Tests: Selected Lower Income Countries}

Table 2A: Cointegration Test Results

Panel Cointegration Test Results (Peacock)

\begin{tabular}{lcc}
\hline & Pedroni & Kao \\
\hline Panel PP-Statistic & $-1.380542^{* * *}$ & - \\
Panel ADF-Statistic & -0.421880 & $2.085149^{* *}$ \\
\hline
\end{tabular}

Johansen Fisher Panel Cointegration Test (Peacock)

\begin{tabular}{ccccc} 
Hypothesized & Fisher stat. & \multicolumn{3}{c}{$\begin{array}{c}\text { Fisher stat. } \\
\text { (from max-eigen }\end{array}$} \\
No. of ce(s) & (from trace test) & Prob. & test) & Prob. \\
\hline None & 63.80 & 0.0000 & 57.05 & 0.0000 \\
At most 1 & 25.78 & 0.0040 & 25.78 & 0.0040 \\
\hline
\end{tabular}

Individual cross section results

\begin{tabular}{lclcc}
\hline & Trace test & \multicolumn{3}{c}{ Max-eign test } \\
\hline \multicolumn{1}{c}{ Cross section } & Statistics & Prob. & Statistics & Prob. \\
\hline Sierra Leone & 52.2025 & 0.0000 & 50.8534 & 0.0000 \\
Tanzania & 5.0824 & 0.8000 & 4.4707 & 0.0866 \\
Ethiopia & 6.2085 & 0.6709 & 4.9745 & 0.07451 \\
Madagascar & 27.6728 & 0.0005 & 24.6932 & 0.0008 \\
DR Congo & 27.1898 & 0.0006 & 16.4563 & 0.0222 \\
\hline
\end{tabular}


Panel Cointegration Test Results (Musgrave)

\begin{tabular}{lcc}
\hline & Pedroni & Kao \\
\hline Panel PP-Statistic & $-1.255319^{* * * *}$ & - \\
Panel ADF-Statistic & $-1.433196^{* * * *}$ & $1.246301^{* * *}$ \\
\hline
\end{tabular}

Johansen Fisher Panel Cointegration Test (Musgrave)

\begin{tabular}{ccccc}
\hline Hypothesized & Fisher Stat. & \multicolumn{3}{c}{$\begin{array}{c}\text { Fisher Stat. } \\
\text { (from max-eigen }\end{array}$} \\
No. of CE(s) & (from trace test) & Prob. & test) & Prob. \\
\hline None & 40.79 & 0.0000 & 33.26 & 0.0002 \\
At most 1 & 25.78 & 0.0040 & 25.78 & 0.0040 \\
\hline
\end{tabular}

Individual cross section results

\begin{tabular}{lcccc}
\hline & Trace Test & \multicolumn{3}{c}{ Max-Eign Test } \\
\hline \multicolumn{1}{c}{ Cross Section } & Statistics & Prob.** & Statistics & Prob.** \\
\hline Sierra Leone & 10.6004 & 0.2373 & 6.0799 & 0.1030 \\
Tanzania & 6.5348 & 0.6323 & 6.5309 & 0.0460 \\
Ethiopia & 32.2137 & 0.0001 & 30.1964 & 0.0001 \\
Madagascar & 20.5715 & 0.0079 & 12.0472 & 0.1089 \\
DR Congo & 18.6600 & 0.0161 & 16.5431 & 0.0214 \\
\hline
\end{tabular}

Panel Cointegration Test Results (Gupta)

\begin{tabular}{lcc}
\hline & Pedroni & Kao \\
\hline Panel PP-Statistic & -0.966977 & - \\
Panel ADF-Statistic & $-4.077866^{*}$ & 1.185293 \\
\hline
\end{tabular}

Johansen Fisher Panel Cointegration Test (Gupta)

\begin{tabular}{ccccc} 
Hypothesized & Fisher Stat. & \multicolumn{3}{c}{$\begin{array}{c}\text { Fisher Stat. } \\
\text { (from max-eigen }\end{array}$} \\
No. of CE(s) & (from trace test) & Prob. & test) & Prob. \\
\hline None & 63.46 & 0.0000 & 52.98 & 0.0000 \\
At most 1 & 29.28 & 0.0011 & 29.28 & 0.0011 \\
\hline
\end{tabular}

Individual cross section results

\begin{tabular}{lrrrr}
\hline & Trace Test & \multicolumn{3}{c}{ Max-Eign Test } \\
\hline \multicolumn{1}{c}{ Cross Section } & Statistics & Prob.** & Statistics & Prob.** \\
\hline Sierra Leone & 13.5064 & 0.0975 & 12.9402 & 0.0801 \\
Tanzania & 31.0262 & 0.0001 & 30.8272 & 0.0001 \\
Ethiopia & 14.2646 & 0.0760 & 10.4241 & 0.1025 \\
Madagascar & 23.5923 & 0.0024 & 20.4092 & 0.0047
\end{tabular}




\begin{tabular}{lllll} 
DR Congo & 37.4487 & 0.0000 & 24.9074 & 0.0007 \\
\hline
\end{tabular}

Panel Cointegration Test Results (Goffman)

\begin{tabular}{lcc}
\hline & Pedroni & Kao \\
\hline Panel PP-Statistic & 0.386583 & - \\
Panel ADF-Statistic & $-2.033907^{* * *}$ & $3.161007^{*}$ \\
\hline
\end{tabular}

Johansen Fisher Panel Cointegration Test (Goffman)

\begin{tabular}{ccccc}
\hline Hypothesized & Fisher Stat. & \multicolumn{3}{c}{$\begin{array}{c}\text { Fisher Stat. } \\
\text { (from max-eigen }\end{array}$} \\
No. of CE(s) & (from trace test) & Prob. & test) & Prob. \\
\hline None & 48.15 & 0.0000 & 33.46 & 0.0002 \\
At most 1 & 33.64 & 0.0002 & 33.64 & 0.0002 \\
\hline
\end{tabular}

Individual cross section results

\begin{tabular}{lcrcr}
\hline & Trace Test & \multicolumn{3}{c}{ Max-Eign Test } \\
\hline \multicolumn{1}{c}{ Cross Section } & Statistics & Prob.** & Statistics & Prob.** \\
\hline Sierra Leone & 24.2333 & 0.0019 & 23.1518 & 0.0015 \\
Tanzania & 5.3755 & 0.7677 & 4.9790 & 0.1045 \\
Ethiopia & 5.9856 & 0.6972 & 5.0125 & 0.0402 \\
Madagascar & 26.4339 & 0.0008 & 17.3553 & 0.0157 \\
DR Congo & 33.4444 & 0.0000 & 20.7941 & 0.0040 \\
\hline
\end{tabular}

Source: Author's computations

\section{APPENDIX 3}

Lag Order Selection Criteria for Causality Tests

Panel 1: Peacock-Wiseman

\begin{tabular}{ccccccc}
\hline Lag & LogL & LR & FPE & AIC & SC & HQ \\
\hline 0 & -70.94748 & NA & 5.048853 & 7.294748 & $7.394322^{*}$ & 7.314186 \\
1 & 58.76495 & 220.5111 & $1.76 \mathrm{e}-05$ & -5.276495 & -4.977776 & -5.218182 \\
2 & 65.56010 & 10.19272 & $1.35 \mathrm{e}-05$ & -5.556010 & -5.058144 & -5.458821 \\
3 & 78.87353 & $17.30746 *$ & $5.55 \mathrm{e}-06$ & $-6.487353^{*}$ & -5.790340 & $-6.351289^{*}$ \\
4 & 91.80822 & 14.22815 & $2.45 \mathrm{e}-06$ & -7.380822 & -6.484662 & -7.205882 \\
5 & 97.09307 & 4.756366 & $2.47 \mathrm{e}-06$ & -7.509307 & -6.414001 & -7.295491 \\
\hline
\end{tabular}

Panel 2: Gupta

\begin{tabular}{ccccccc}
\hline $\mathrm{Lag}$ & $\mathrm{LogL}$ & LR & FPE & AIC & \multicolumn{1}{c}{ SC } & HQ \\
\hline 0 & -82.55350 & NA & 16.11520 & 8.455350 & 8.554924 & 8.474788 \\
1 & 64.22047 & 249.5158 & $1.02 \mathrm{e}-05$ & -5.822047 & -5.523327 & -5.763734
\end{tabular}




\begin{tabular}{lllllll}
2 & 69.67263 & 8.178246 & $8.97 \mathrm{e}-06$ & -5.967263 & -5.469397 & -5.870075 \\
3 & 79.05101 & 12.19189 & $5.45 \mathrm{e}-06$ & -6.505101 & -5.808089 & -6.369037 \\
4 & 93.87652 & $16.30806^{*}$ & $2.00 \mathrm{e}-06$ & -7.587652 & -6.691493 & -7.412712 \\
5 & 101.1645 & 6.559227 & $1.64 \mathrm{e}-06$ & -7.916455 & -6.821149 & -7.702640 \\
6 & 105.0479 & 2.718333 & $2.09 \mathrm{e}-06$ & -7.904788 & -6.610336 & -7.652097 \\
7 & 114.1249 & 4.538516 & $1.86 \mathrm{e}-06$ & -8.412491 & -6.918893 & -8.120925 \\
8 & 134.9812 & 6.256882 & $7.16 \mathrm{e}-07 *$ & $-10.09812^{*}$ & $-8.405374^{*}$ & $-9.767677^{*}$ \\
\hline
\end{tabular}

Panel 3: Goffman

\begin{tabular}{ccccccc}
\hline Lag & LogL & LR & FPE & AIC & SC & HQ \\
\hline 0 & -194.7768 & NA & 8.982938 & 7.871070 & 7.947551 & 7.900195 \\
1 & 149.2893 & 646.8441 & $1.11 \mathrm{e}-05$ & -5.731570 & -5.502128 & -5.644197 \\
2 & 162.2712 & 23.36748 & $7.77 \mathrm{e}-06^{*}$ & -6.090848 & -5.708443 & $-5.945226^{*}$ \\
3 & 164.4526 & $3.752068^{*}$ & $8.38 \mathrm{e}-06$ & $-6.018105^{*}$ & $-5.482739^{*}$ & -5.814235 \\
4 & 169.2842 & 7.923708 & $8.14 \mathrm{e}-06$ & -6.051366 & -5.363038 & -5.789247 \\
5 & 172.7720 & 5.441055 & $8.36 \mathrm{e}-06$ & -6.030881 & -5.189591 & -5.710513 \\
\hline
\end{tabular}

Panel 4: Musgrave

\begin{tabular}{ccccccc}
\hline Lag & LogL & LR & FPE & AIC & SC & HQ \\
\hline 0 & -52.40830 & NA & 0.790762 & 5.440830 & 5.540403 & 5.460267 \\
1 & 27.53405 & 135.9020 & 0.000400 & -2.153405 & -1.854685 & -2.095092 \\
2 & 38.54023 & 16.50927 & 0.000202 & -2.854023 & -2.356157 & -2.756834 \\
3 & 43.75887 & 6.784235 & 0.000186 & -2.975887 & -2.278875 & -2.839823 \\
4 & 52.69462 & $9.829324 *$ & 0.000123 & -3.469462 & -2.573303 & -3.294523 \\
5 & 57.93499 & 4.716329 & 0.000124 & -3.593499 & -2.498193 & -3.379684 \\
6 & 64.64217 & 4.695029 & $0.000119 *$ & $-3.864217 *$ & -2.569765 & $-3.611527 *$ \\
7 & 69.76135 & 2.559587 & 0.000157 & -3.976135 & -2.482536 & -3.684569 \\
8 & 78.32933 & 2.570396 & 0.000207 & -4.432933 & -2.740189 & -4.102492 \\
\hline
\end{tabular}

Panel 5: Mann

\begin{tabular}{ccccccc}
\hline Lag & LogL & LR & FPE & AIC & SC & HQ \\
\hline 0 & -51.16308 & NA & 0.698180 & 5.316308 & 5.415882 & 5.335746 \\
1 & 20.63248 & 122.0525 & 0.000797 & -1.463248 & -1.164529 & -1.404935 \\
2 & 35.31765 & 22.02775 & 0.000279 & -2.531765 & -2.033899 & -2.434576 \\
3 & 38.92919 & 4.695005 & 0.000301 & -2.492919 & -1.795906 & -2.356855 \\
4 & 44.57040 & 6.205327 & 0.000276 & -2.657040 & $-1.760881 *$ & -2.482100 \\
5 & 48.85021 & $3.851829 *$ & $0.000307 *$ & -2.685021 & -1.589715 & $-2.471206 *$ \\
6 & 56.39650 & 5.282402 & 0.000271 & -3.039650 & -1.745198 & -2.786959 \\
7 & 71.40365 & 7.503576 & 0.000133 & -4.140365 & -2.646766 & -3.848799 \\
8 & 91.45702 & 6.016011 & $5.56 \mathrm{e}-05$ & -5.745702 & -4.052957 & -5.415260 \\
\hline
\end{tabular}

* indicates lag order selected by the criterion

LR: sequential modified LR test statistic (each test at 5\%

level)

FPE: Final prediction error

AIC: Akaike information criterion 
SC: Schwarz information criterion HQ: Hannan-Quinn information criterion

Source: Author's computations 